\title{
Negating Seth: Destruction as Vitality
}

\author{
Janne Arp-Neumann \\ Institute for Egyptology and Coptic Studies, Georg-August-Universität \\ Göttingen, Germany \\ jarp@uni-goettingen.de
}

\begin{abstract}
In the past, different points in time have been set as demarcating the beginning of the end of Ancient Egyptian religion. One of these is the start of the so-called "proscription" of the god Seth, whose names and images are found damaged in many of their occurrences. In previous studies, this observation was explained as the result of intentional destruction performed during the first millennium BCE, and as such as indicative of the decay of Ancient Egyptian religion at this time. However, Seth was from his earliest attestations conceived as a deity ready to perform acts of violence and disruption; under specific circumstances he needed to be banished, but his character was also valued in circumstances requiring violence. This article discusses the problems, fallacies, and arguments of interpreting the intentions behind the destruction of monuments in general and the treatment of Seth in particular. It will be argued that "negating" the image of the "negative" god was not done with malicious intent, but to highlight this god's role, which was important for the context of the image. It will be proposed that this phenomenon proves that Egyptian religion was still vibrantly alive at that time, not fading away and dying.
\end{abstract}

\section{Keywords}

Ancient Egyptian religion - Seth (god) - collapse - demise of religion - destruction of names and images - negative god 
The religion of the Ancient Egyptians used many names, forms, and constellations to describe entities of supernatural power (Hornung 1996). The Egyptian temples were built as models of the world and places for the gods to dwell, being taken care of vicariously by the pharaoh and, in substitution, the priests (Eaton 2013). The pharaoh was considered as intermediary between the gods and humankind, and expected to uphold "Maat," the Egyptian concept of balance and order (Assmann 2006). Seth was one of those supernatural powers for whom temples were built and ritual practices performed.

Seth's particularity as a deity was picked up on by Egyptologists, who called him "god of confusion" (te Velde 1967), or a "complex god" (Turner 2013: 68-70). But already in the mid-19th century, a Prussian mission to Egypt observed that on many walls of numerous temples, the images and names of Seth had been damaged (Lepsius 1851: 51). Since no monuments dedicated to Seth dating to a time after the 21st dynasty were known in these early days of Egyptology, the damage was assumed to have been inflicted by a second hand with the intention to harm the god and erase him from the temple walls. This assumption was related to the fact that the Egyptians had experienced foreign invasions in the first millennium BCE. Henceforth, most Egyptologists agreed - and still do today - that the Egyptians had started to turn against the god, whom they assumed to have been the invaders' accomplice, that Seth had become an "anti-icon" (Wilson 2005: 125), a "symbol of foreign domination over Egypt" (Brand et al. 2013: 202), and that he was consequently made a target of proscription. Moreover, the phenomenon of a "widespread iconoclasm against this once worshipped god" was considered to signal a "striking change in Egyptian belief" (Wilson 2005: 125; cf. Smith 2010: 414).

This article will make a case for applying a new perspective to the analysis of the phenomenon of the destruction of the image and name of Seth. The challenge lies in the fact that at first glance, the treatment of this god certainly looks like the result of hateful persecution. In a first step, this article will therefore outline the wide spectrum of meaning that transformations of monuments can have that should be considered when assessing the intentions behind the treatment of Seth. In a second step, a short outline of the roles and forms of the god Seth will be given, and in a third step, selected examples of supposed proscription, not only in relief but also in papyri, will be examined in context. This article concludes that the transformation of Seth was not intended to annihilate this god, but in fact to highlight his still important role. It proposes that the effort itself proves that Ancient Egyptian religion was not 
in decay, nor in a "vacuum" (Hubai 2001: 89), when the names and figures of Seth were transformed, but, on the contrary, in action.

\section{Interpreting the Intentions behind the Destruction of Monuments}

\subsection{Toppled Monuments = Collapsed Society?}

Jared Diamond claimed that societies can only survive if they adapt to changing circumstances, while societies that do not change are bound to collapse (Diamond 2005). He took Percy Bysshe Shelley's poem “Ozymandias" (1817) as a starting point for his thought-provoking, influential, and at the same time controversial book. In this poem, the following phrase is said to be written on the pedestal of a colossal statue: "My name is Ozymandias, king of kings: / Look on my works, ye Mighty, and despair!" The name and the idea of such an inscription derive from an account by Diodorus Siculus (dating to around the middle of the first century BCE), which most probably referred to the fragments of a granite statue of Ramesses II (ca. 1279-1213 BCE) ${ }^{1}$ in his mortuary temple, the so-called Ramesseum at Western Thebes in Egypt (Griffiths 1948: $82-83)$. The statue of Ozymandias was described by Diodorus as being intact, but the "traveller from an antique land" from Shelley's poem found it in a different state: "Two vast and trunkless legs of stone / Stand in the desert. Near them, on the sand, / Half sunk, a shattered visage lies" (Diamond 2005: viii). Diamond points out, that the "scales of the ruins testify to the former wealth and power of their builders ... Yet the builders vanished, abandoning the great structures that they had created at such effort" (3). He ends this line of thought asking: "How could a society that was once so mighty end up collapsing" (3).

Diamond rightly chose to use the term "societies" instead of "cultures," but he is wrong in deducing the collapse of society basically from changes in culture (cf. Maggio 2017: 50-51): taking the famous monuments of Easter Island as an example, Diamond claimed that the society which once erected these statues had collapsed because this practice had wasted resources. However, if the society had simply stopped this practice on its own account, it would also have lost what Diamond takes as proof of continuity and evidence of might.

The problem is of course a bit more complicated: Diamond, following others, assumed that the monument-erecting society on Easter Island had collapsed because it was superseded by another, monument-destructing society.

1 The dates and periodization of Ancient Egyptian history given throughout this article are following the chronology given by Shaw 2000. 
The former practice did not only stop at some point in time, but the statues were also subsequently toppled (Diamond 2005: 90). The readers of Diamond's book are prepared to think of Ozymandias's fate and to see the correlation between waste of resources, collapse, and successive societies acting more wisely. But it should be noted that the practice of toppling the monuments on Easter Island was making use of the same resources as the former (ropes, timber, stone, nutrition, work force, expert knowledge, artisans' skills), while the level of complexity had increased: the statues were systematically tipped over, intentionally broken with slabs of stone put underneath the spot where they fell, and they were furthermore inscribed afterwards (110-111). Hence, instead of supposing a collapse of society due to the waste of resources in the time between erecting and toppling the statues, it is more plausible to assume a change in culture (cf. also McAnany and Yoffee 2010). All that was done to the monuments could have been done by the same population of Easter Island for a wide variety of reasons.

\subsection{Iconoclasm and damnatio memoriae vs. Destruction, Deconstruction, and Transformation}

Ancient Egypt is studied primarily by analyzing monumental sources: temples and tombs constructed from stone, furnished with reliefs showing images and bearing hieroglyphic texts. Due to environmental and human influence in subsequent periods, the reliefs lost their colors and the walls collapsed, broke into pieces, were built up again or reused for something else. Penelope Wilson pointed out that the material of images was often destroyed inadvertently due to touching by visitors, but also by purposeful gouging (Wilson 2005: 115f). Consequently, the sources are usually damaged (cf. Kristensen 2013: 110-111; Connor 2018: 147), and in a double sense of the word, this is the image of a ruin (cf. Stapelton and Viselli 2019: 8).

But if a relief has specifically and clearly been targeted, a second hand and malicious intention are usually suspected to have conducted the damage. Such a case is addressed as damnatio memoriae, when names and other means of identification are affected, or as "iconoclasm," when images that were charged with ostensibly objectionable meaning are affected (cf. Connor 2018: 147). The most extensively discussed cases of these two phenomena in Egyptology are: (1) The conjectured persecution of the images and names of the god Amun (and other gods), supposed to have been executed on behalf of king Akhenaten during the so-called Amarna-period (ca. 1352-1295 BCE), and to have been restored by Akhenaten's successors (Quack 2019: 55-57); (2) the conjectured obliteration of the memory of the female pharaoh Hatshepsut (са. 1473-1458 вСЕ), supposed to have been executed on behalf of her co-regent, rival and, finally, 
successor Thutmosis III, either at a later point in his reign, which is the dominant interpretation, or immediately after her death (Quack 2019: 66-67). Many scholars dealing with these two cases, and that of the conjectured proscription of Seth, have observed that the images and texts are never destroyed completely and that there are always exceptions to any pattern one might have found to explain the phenomena (e.g., Connor 2018: 16o). These observations emphasize the necessity of reconsidering the full range of possible intentions of acting with and eventually destroying images.

In Ancient Egypt, images on monuments and papyri were always charged with meaning, one could even say that the very motivation to produce them was to charge them with meaning (Lorton 1999). The special way of representing beings and objects in Egyptian art is called "aspective," a term coined to address the fact that the dominating factor of composition was not the perspective of the beholder, but the intention to encompass all relevant aspects of any being or object to be represented (Brunner-Traut 2002 [1974]). The "Opening of the Mouth" ritual is known to have been carried out to "activate" lifeless bodies (images in relief, statues, and mummies), in order to prepare them to accommodate the "souls" of the represented beings (cf. Lorton 1999; Connor 2018: 149). Consequently, the damaging of an Egyptian image can be seen as a reversal of the Opening of the Mouth ritual, a "deactivation" of the image (Connor 2018: 153).

As Betsy Bryan pointed out, following David Lorton, the production of images was in itself violent and destructive, although scholars still do not rate the process of breaking the image out of the material as destructive, but as transformative (Bryan 2012: 363 ). ${ }^{2}$ Moreover, the violation of an image could also have been part of its design in Ancient Egyptian sources. Human beings and animals which figured as signs in the script were in some cases - for example, in tombs where they were felt to pose danger to the tomb owners modified so as to be still readable as signs but incomplete or mutilated in their figurativeness (Ritner 2012: 398). The motifs of bound prisoners and enemies to be smitten on Egyptian monuments can also be seen in this light (Ritner 2008: 111-143). These images were not at all negated by the violence executed on them, in fact they were positively used to banish what they represented.

In the context of their production, Egyptian reliefs experienced further transformations, which cannot be valued negatively: when the ancient artisans made mistakes, or struggled with veins in the stone that disrupted parts of the relief, they fixed these problems by chiseling and plastering, by rewriting

2 It is interesting to note in this regard that the tools for working the images out of stone or wood were also used in the ritual of Opening of the Mouth. 
the hieroglyphs, and reshaping the figures (e.g., Nelson 1936). Artisans also changed names and images after the production of the reliefs was completed, for example when a king changed the writing of his name or the style of the representation of his own figure or that of a god (Nelson 1936: viii). However, after several hundred years, when the plaster happened to be broken off, chisel marks are laid open which could look like the result of damage done by a second hand toward specific targets with malicious intent (Nelson 1936: Plate 9E).

Carina Kühne-Wespi et al. (2019: 18) discussed an example of a stela of a woman whose status had changed from widow to wife after the stela had been produced. For the inscription still to be accurate and beneficial for that woman, the term designating her former status was deleted. Natalie Naomi May has given a similar example from the Ancient Near East and called this form of transformation with neutral or even beneficial intentions "deconstruction" of an image to assign new meaning to it (May 2012: 8). Reuse and usurpation are also generally understood as a deconstruction and assignment with new meaning (Wilson 2005: 126; Brand 2010a, 2010b; Connor 2018: 149). Not malicious, although surely not altruistic either, is the deconstructive practice of restoration that is widely attested in Egyptian temples. Here, it is also called "deconstructive" rather than "reconstructive," because these initiatives actually did not only restore the images to the state they had been in before, but also changed and assigned new meaning to them (Connor 2018: 149-150).

Of particular interest in this regard is the idea that the deletion of the name and image of the god Amun from private tombs at Thebes might have been done with the intention to release the temple of Amun from the codified obligation to provide offerings for the respective tombs (cf. Bryan 2012: 375). Hence, transforming these reliefs by deleting the god had a beneficial intention with regard to the god. And the termination of cultic responsibility could also be a suitable explanation for the deletion of a figure of a certain priest in many of the Theban private tombs (389). Moreover, both Ancient Near Eastern and Ancient Egyptian cultures deconsecrated images, which they chose to no longer assign with new meaning (May 2012: 8). Bryan drew attention to the Egyptian practice of "caching" statues, when "retired images" were put in the so-called cachettes of a temple, where they "simply slept" (2012: 369). These cached statues were usually just discarded, but in some special cases, images were purposefully destroyed before depositing them. In the case of the statuary of Hatshepsut from her temple at Deir el-Bahari (as part of case (2), see above), Simon Connor calls this practice a "deactivation" (Connor 2018: 153; for other examples of deactivation, also in a context of reuse, see 158-160). This could have had malicious intention toward what was represented, but it could also have been employed with the beneficial motivation to release the 
material from its former function, because it was not intended to assign a new meaning to it.

\section{The Character and Roles of the God Seth}

The Egyptians had many explanations for how to understand the world, in which different gods featured in different ways. Seth belonged to the nine gods of the "Ennead of Heliopolis," which was one group of gods among many (Hornung 1996:146-147). The first of the nine was Atum, who brought Shu and Tefnut into being, representing air and humidity, who then created Geb and Nut, representing earth and heaven. These in turn gave birth to Osiris, Seth, Isis, and Nephthys. Seth, however, was a misfit from the beginning, born in an untimely and unusual way, breaking through his mother's side (Turner 2013: 62) or being spat out (Kahl 2004: 238), according to different strands of tradition.

The "myth of Osiris" deals with the last generation of the Heliopolitan creation and explains the conditions of life on earth. Many different Egyptian sources from all periods allude to the stories connected with this myth and the dramatis personae played decisive roles in fundamental spheres of Ancient Egyptian culture throughout Egyptian history. Osiris was the prototype for the dead, especially the dead king, and Horus the prototype for the rightful living king. Isis was the caregiver, who used special capacities for hiding, finding, defending, healing, etc., and therefore was often referred to in medico-magical texts. Seth's role was that of a destructive power which could be used for evil but also for good (Cruz-Uribe 2009). However, in narrative form the myth has been preserved only in an account by Plutarch, from around the first century CE (Griffiths 1970). According to this narrative, Osiris used to be king of the living, but Seth tricked and murdered him, cut him to pieces and scattered these pieces throughout the country. Osiris's wife Isis collected the limbs and with the help of Nephthys and Anubis (Nephthys's son) created the first mummy, so that Osiris was able to live on in another form of existence as the king of the dead. With her dead husband, Isis conceived their son Horus, who was to become king of the living following his father. In a sequel to this main part of the story - which has come down to us in narrative form on a papyrus known as "Chester Beatty 1," dating to the 2oth dynasty (1186-1069 BCE) - the "Contendings of Horus and Seth" (Gardiner 1931; Oden 1979), Seth fought for his right to the throne, but was finally defeated. Instead of the throne, he took the place in the prow of the bark of Ra to repel the sun god's enemy Apophis. This position was of the highest importance for maintaining Maat, and for this his fierce character was more than suitable. 

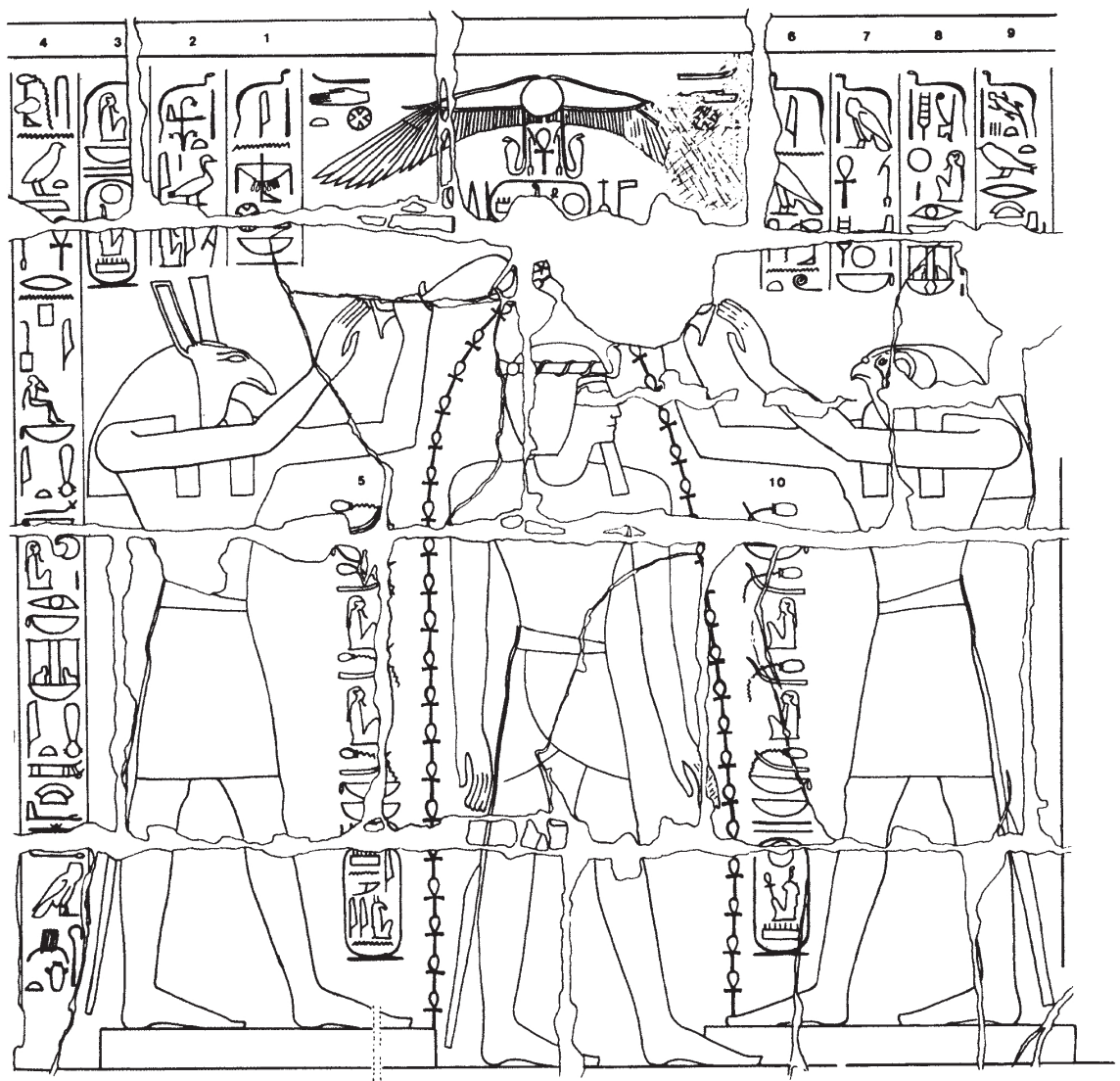

FIGURE 1 Seth, called Nubty (meaning: the Ombite), to the left, and the falcon-headed Horus to the right, purifying the Ramesside King Sety I (1294-1279 BCE) in the middle. Relief in the Great Hypostyle Hall in the temple of Amun-Re at Karnak NELSON AND MURNANE 1981: PL. 148

Egyptian gods were not only numerous, but each also had several forms: anthropomorphic, theriomorphic, and mixed, usually with an animal's head on a human body. In the form that was primarily subject to transformations, Seth was represented as or with the head of the "Seth animal" (Fig. 1). All attempts to reconcile this form with a known animal have so far failed, even if the African wild dog with regard to the general dog-like shape of the body, the broadening ears, and the upright tail seems to come close (Turner 2013: 10). However, the snout of the Seth animal is slightly bent downwards, resembling a beak, and the ears are characteristically square-topped (Kooyman 2017:366). A full match with a natural being is most probably not to be expected because the unnatural form may have been intended to represent his character of a 
misfit. Other forms in which Seth was represented were those of the hippopotamus, the antelope, and the donkey. Last but not least, Seth was depicted as the Canaanite god Bacal, and the name of Ba'al was written with the Seth animal as a classifier (Allon 2007; Kooyman 2017: 371-372).

Phillip John Turner's book on the development of the role and importance of Seth in the history of Ancient Egyptian religion is the latest monographic study of this god (Turner 2013). Turner retraced the hypothesis that was already formulated by Karl Richard Lepsius in 1851 and further developed by other scholars. According to them, there was a peak in the attention given to Seth when he was a favorite of the Ramesside kings of the 19th dynasty (1295-1186 BCE), but after that period, beginning supposedly with the 21st dynasty (1069 BCE), his image and name - both using the Seth animal - were destroyed (Turner 2013: 47). However, sources produced after the 21st dynasty up to the Greco-Roman period (beginning 332 BCE) still mentioned and depicted Seth (Turner 2013: 48-59), and in these occurrences, according to Turner, he was addressed "negatively" as well as "positively" (2013: 51-52, 53). Turner therefore came to a revised conclusion: the "demonization" of Seth happened only in the Nile valley after the Assyrian and Persian invasions, in the Late Period (26th-3oth dynasty, 664-332 вСЕ) (54), while his cult in the oases continued to be active (Turner 2013: 49; cf. Hope and Warfe 2017; Kooyman 2017; Vittmann 2017).

However, the correction of the "misrepresentation" of this god can be taken even further than this. In the same year as Turner's monograph was published, David Klotz presented proof that in the Late Period the god was not proscribed in the Nile valley either (Klotz 2013). And while Turner had been following others in considering the forms of hippopotamus, antelope, and donkey to be "negative" treatments of the god in the Late Period (Turner 2013: 59), Milena Kooyman recently proved this wrong, because the hippopotamus-form, for example, was used already on private stelae of the New Kingdom, which were dedicated to Seth as a personal patron (2017: $\left.365^{-370}\right)$. And it also needs to be considered, what had been pointed out already by Herman te Velde (1967) in the first monograph devoted to this god, that the Seth animal was avoided in specific contexts already in the earliest times, beginning with the Old Kingdom (Quack 2019: 58), as well as, for example, by the Ramesside kings in the temple of Abydos, which was dedicated to Osiris (te Velde 1967: 132; cf. Cruz-Uribe 2009: 203).

It has become conventional in Egyptology to differentiate the sources according to the treatment of Seth as "positive" or "negative," his actions as "good" or "bad" (e.g., Turner 2013). However, for the Egyptians, it seems that there was no contradiction in the fact that Seth acted in good and bad ways, and was treated positively and negatively, at the same time (cf. Smith 2010: 
413). Mark Smith already proposed to accept that "how Seth is portrayed in a given source is determined by the nature of that source" (2010:415). Moreover, to fully understand this god's role, one has to acknowledge the positive effects not only of his good actions on the prow of the bark of Ra, but also of his bad actions toward Osiris and Horus. In the ancient Egyptian sources, Osiris was the god who died, who had to die, to give way to the next generation of the living, but also to pave the way for the future dead. And Seth was the one who trespassed boundaries, the one to whom rules did not apply. Hence, he was the god who provided a reason for and was able to execute the necessary death of Osiris. Both Osiris and Seth had to play exactly the roles that they played in relation to each other, as prototype on the one hand, and misfit on the other. If Osiris had not died, Horus would not have become king, and Seth would not have repelled the enemy of the sun god.

Since Seth was connected to boundaries in general and to crossing boundaries in particular, he received cultic attention especially in liminal regions: a temple at Ombos in Upper Egypt and others in the oases were devoted to this god (Turner 2013). In funerary contexts he could take the role of defensive power, when the daily journey of the bark of the sun god Ra was addressed (Du Quesne 1998). However, his role as the enemy of Osiris and Horus was also alluded to in ritual texts that have been written down on funerary papyri and temple walls, to evoke the mythological precedents of death being overcome, of wounds being healed, and of justice being dispensed (the "Daily Cult Ritual"; cf. Lorton 1999, and see below).

\section{The Transformation of the Name and Image of the God Seth} in Context

To give a description of the distribution, quantity, and quality of the representations of the god Seth is a difficult task, for as yet no in-depth study has collected and analyzed all the cases together. Te Velde has referred to the phenomenon as being "common knowledge" (1967: 146), and others following him did not treat the transformations of the reliefs as sources either (Fazzini 1988; Turner 2013). However, a comprehensive study of these cases can finally be expected to be published in the near future. ${ }^{3}$ In 2017, Colin A. Hope and Ashten R. Warfe discussed selected cases of damage (not) done to images and names of Seth in the Nile valley (in the temple of Seth at Ombos/Nubt and in the reliefs of Seti I

3 https://research.monash.edu/en/projects/seth-god-of-confusion-the-archaeology-of-a-cult -centre-in-egypt (accessed 3 July 2020). 
in Karnak) and declared that the situation was far more complex, with targets other than Seth being damaged in the same manner and with Seth having been left undamaged in easily reachable places. They stated that in future scholarship the representations of Seth would need to be analyzed in context (Hope and Warfe 2017: 281).

The importance of this appeal can be seen when looking at an example that has recently been selected and interpreted in the conventional way by Joachim Friedrich Quack (Quack 2019). Quack referred to two plates of the documentation of the Prussian mission to Egypt (see above), which were published in the twelve volumes of Karl Richard Lepsius's Denkmäler aus Aegypten und Aethiopien from 1849 to 1859 (Quack 2019: 58 ). ${ }^{4}$ He referred to Lepsius's figures $35 \mathrm{e}$ and $36 \mathrm{~b}$ of the third volume of the plates (here Fig. 2), pointing out that the images and names of Seth were chiseled out in these two reliefs and interpreting this as proof for a proscription of the god (Quack 2019: 58).

These two figures (Fig. 2) show drawings of reliefs in the "Nebenräume der hinteren Säulenhalle," as Lepsius called the location, which today is known as part of the "Akhmenu" or "Festival Temple" of Thutmosis III in the precinct of the Great Temple of Amun at Karnak. As can be seen in Figure 2, Lepsius's plates used stippling and lacunae to indicate transformation in the relief. It should be noted, however, that stippling was used when the object was still recognizable to Lepsius, either because enough material and/or shape was left, or because the image was restored in ancient times. Lacunae were used for those parts of the images where nothing was left to be recognized. Consequently, one problem with Quack's interpretation of these figures is that they are not explicit in the treatment of the god Seth. But looking at them, another problem becomes clear: Quack has also left the context unnoticed. Seth (here called "Nubty," meaning the one from Ombos) is not the only god who has suffered transformation in these two reliefs. Lepsius's figure 35e (Fig. 2) shows the king between the god Seth and the goddess Nephthys, and the images of both deities as well as their names are drawn with stippling. And in Lepsius's figure $36 \mathrm{~b}$ (Fig. 2) there are even more targets of stippling discernible than just Seth: the image of a priest with his title, a falcon-headed god, the topmost lines of inscription above the king, and the name "Behedety," meaning the one from Edfu, which alludes to the god Horus.

Moreover, on Lepsius's plate 35, there are more figures showing drawings of reliefs which come from the same location and also indicate transformation of Seth and other deities; but these were disregarded by Quack as well. In these

4 The volumes were printed without a year of publication, therefore reference can only be given to the timeframe of publication from the first to the last instalment. 

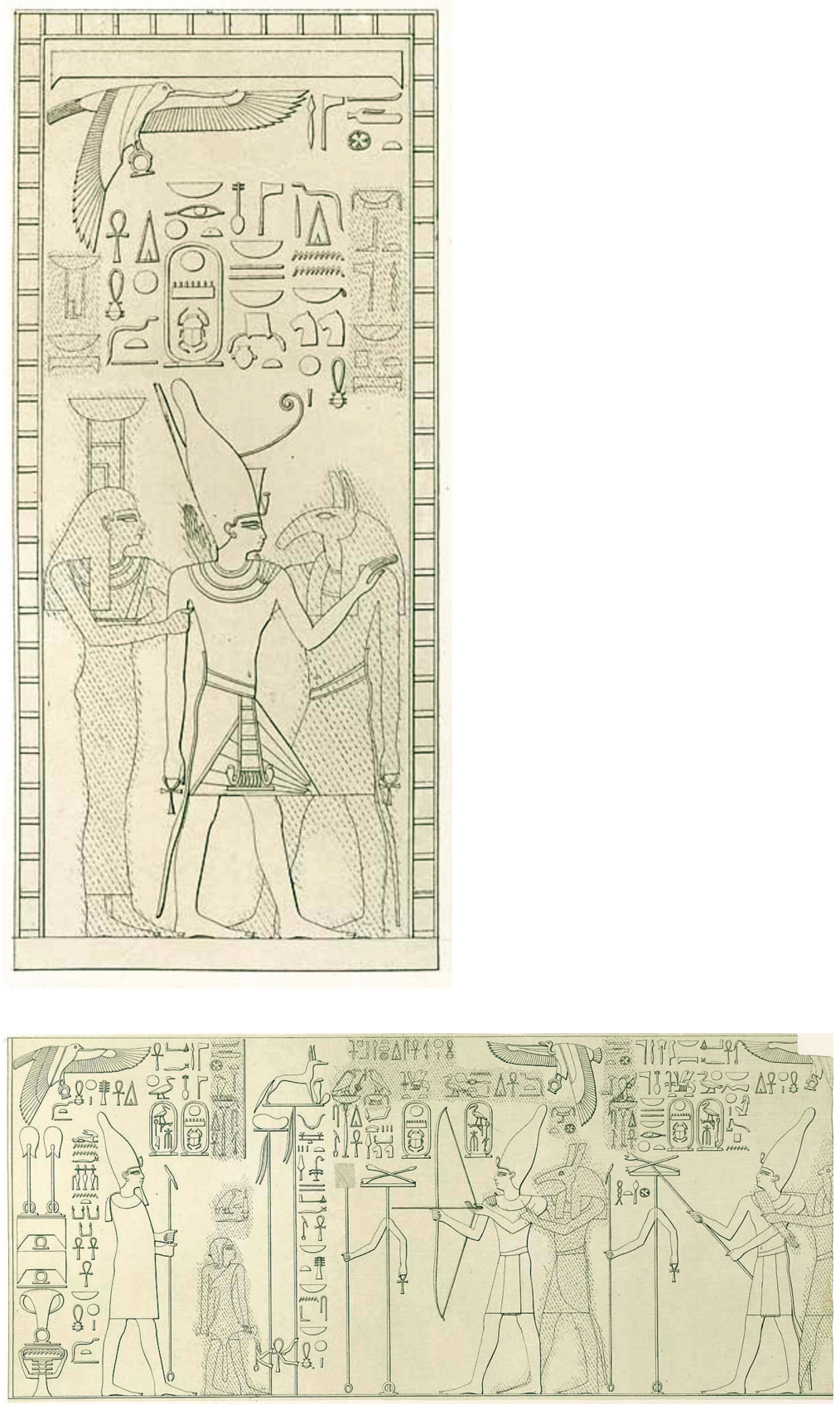

FIGURE 2 Lepsius 1849-1859: fig. 35e (Karnak, Festival Temple, room XV, wall 365, after Porter and Moss 1929) and fig. 36b (Karnak, Festival Temple, corridor VI, wall 354, after Porter and Moss 1929) 
other reliefs, two images of Seth are drawn in lacuna (once fully, once partly in lacuna and partly in stippling), but still identifiable, because his name, Nubty, was not transformed. ${ }^{5}$ Other targets in this plate are the headdress of the god Amun, which is stippled, while parts of his name are in lacunae; and the image and name of the god Montu are stippled, while the god Atum is unmarked. ${ }^{6}$ Not mentioned by Quack either are plates 33 and 34 in Lepsius's volume, even though they also show reliefs with diverse transformations from the same location. ${ }^{7}$ One of these figures, however, has used stippling only for the inscriptions, while the image of Seth was wrongly left unmarked. As the comparison with a photograph proves, the relief was indeed transformed, but restored afterwards (Fig. 3).

It should be noted that the documentation represented in all these plates was made by the same scholar, who was the first to address the phenomenon of a supposed persecution of Seth (see above), and that the hypothesis was actually based on these reliefs. He was also the originator of the hypothesis of a persecution of the god Amun (see above, case (1)). But Lepsius only documented selected walls of this part of the Karnak temple, and the drawings of these are far from accurate. The corresponding text volume does not explain the details of transformations made to the relief either: the figures are described only cursorily, claiming that all gods, including Seth, had been persecuted under Akhenaten and restored by his successors, and that Seth was hacked out a second time and plastered over (Lepsius 1900: 33). ${ }^{8}$ Regarding the images and names of Seth that were restored and not attacked afterwards, Lepsius speculated that they might have been restored after the execution of the proscription or overlooked during the process (Lepsius 1900: 35 ).

5 Lepsius 1849-1859, fig. 35a (Karnak, Festival Temple, room XXII, wall 380, after Porter and Moss 1929) and fig. 35b (Karnak, Festival Temple, room XXII, wall 380, after Porter and Moss 1929).

6 Lepsius 1849-1859, fig. 35c (Karnak, Festival Temple, room xxi, wall 377, after Porter and Moss 1929) and fig. $35 f$ (Karnak, Festival Temple, room XV, pillar I, side c, after Porter and Moss 1929 .

7 Lepsius 1849-1859, fig. 33a (Karnak, Festival Temple, room XxI, pillar II, side h, after Porter and Moss 1929), fig. 34a (Karnak, Festival Temple, room Xx, pillar I, side c, after Porter and Moss 1929), fig. 34b (Karnak, Festival Temple, room XXI, pillar II, side g, after Porter and Moss 1929), and fig. 34c (Karnak, Festival Temple, room XXII, pillar I, side d, after Porter and Moss 1929).

8 Although this volume was published posthumously in 1900, this was done on the basis of Lepsius's diaries, his notes, the objects he brought to Berlin, and the sketchbooks of his staff. The texts were even written from Lepsius's perspective, using the first-person plural in comments specifying the rooms of the temple in which Lepsius and his team used to sleep and cook during their stay. 

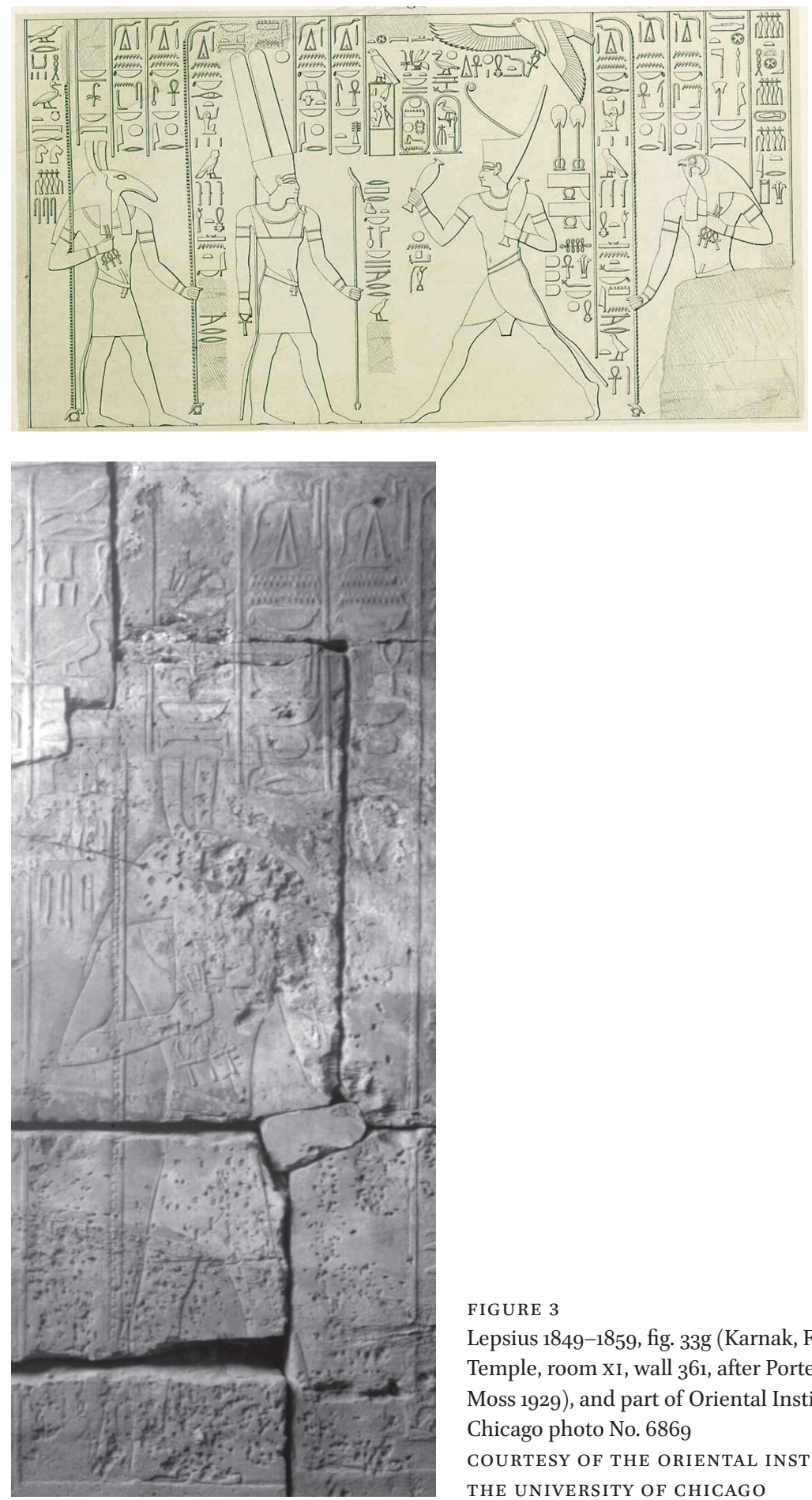

FIGURE 3

Lepsius 1849-1859, fig. 33g (Karnak, Festival Temple, room XI, wall 361, after Porter and Moss 1929), and part of Oriental Institute Chicago photo No. 6869 COURTESY OF THE ORIENTAL INSTITUTE OF THE UNIVERSITY OF CHICAGO 
A look at photographs from the archive of the Oriental Institute Chicago (here Figure 4), corresponding to Lepsius' fig. 35e and 36b shown in Figure 2 allows us to give a more precise description of the treatment of Seth in these two reliefs. In the first case, Nephthys and Seth both have been transformed in a way that left a very low relief in comparison to the image of the king in the middle. This must be the state which Lepsius addressed as restored and not attacked a second time. In the second case, there are traces of hacking with an instrument that left holes spread in a perpendicular pattern over Seth and the falcon-headed god. But there are also other marks left on Seth's head only, which have the form of strokes spread in a horizontal pattern. This must be the state which Lepsius interpreted as a secondary attack against Seth alone. However, there are more observations to be made, which are not explained by the hypothesis of two periods of persecution: Seth is still recognizable, or even more so with the horizontal strokes to his head (cf. Wong 2016: 93). Another important aspect to be noted is that whatever was done to the figures, it was done by keeping damage close to the silhouettes and not affecting their surroundings too much. ${ }^{9}$ The figure of the king is often crossed by transformed hands and arms and his hands and arms often cross transformed bodies, but his outlines were always kept intact.

The comparison of the reliefs of this location at Karnak temple can also be extended to Figure 1, which was given above to illustrate the special form of the head of the Seth animal. In this example, both Seth and Horus are to be seen without any mark of transformation (cf. Brand et al. 2018: 75), which according to Lepsius's hypothesis would mean that it accidentally escaped both periods of persecution. This relief is to be found in the Great Hypostyle Hall of Karnak temple, which is not far from the reliefs documented by Lepsius, and in an even more prominent place than those. Consequently, these selected examples of reliefs demonstrate that a convincing explanation of the principles directing the transformations has not yet been found and the results from more profound and contextualizing analysis, as for example aimed at by the Australian project of Hope and Warfe (2017), need to be awaited.

Moreover, contextualization in the future needs to include other media than relief, because the name and image of Seth were in fact transformed in hieratic writing on papyri, too. A papyrus kept in Berlin (No. 3055) is a very

9 The holes left by the first attack spread far above the falcon-headed god, but this extent of damage is quite unusual, and therefore it rather suggests that there was another headdress, or maybe another god's figure altogether, before the image visible in the drawing was "restored." 

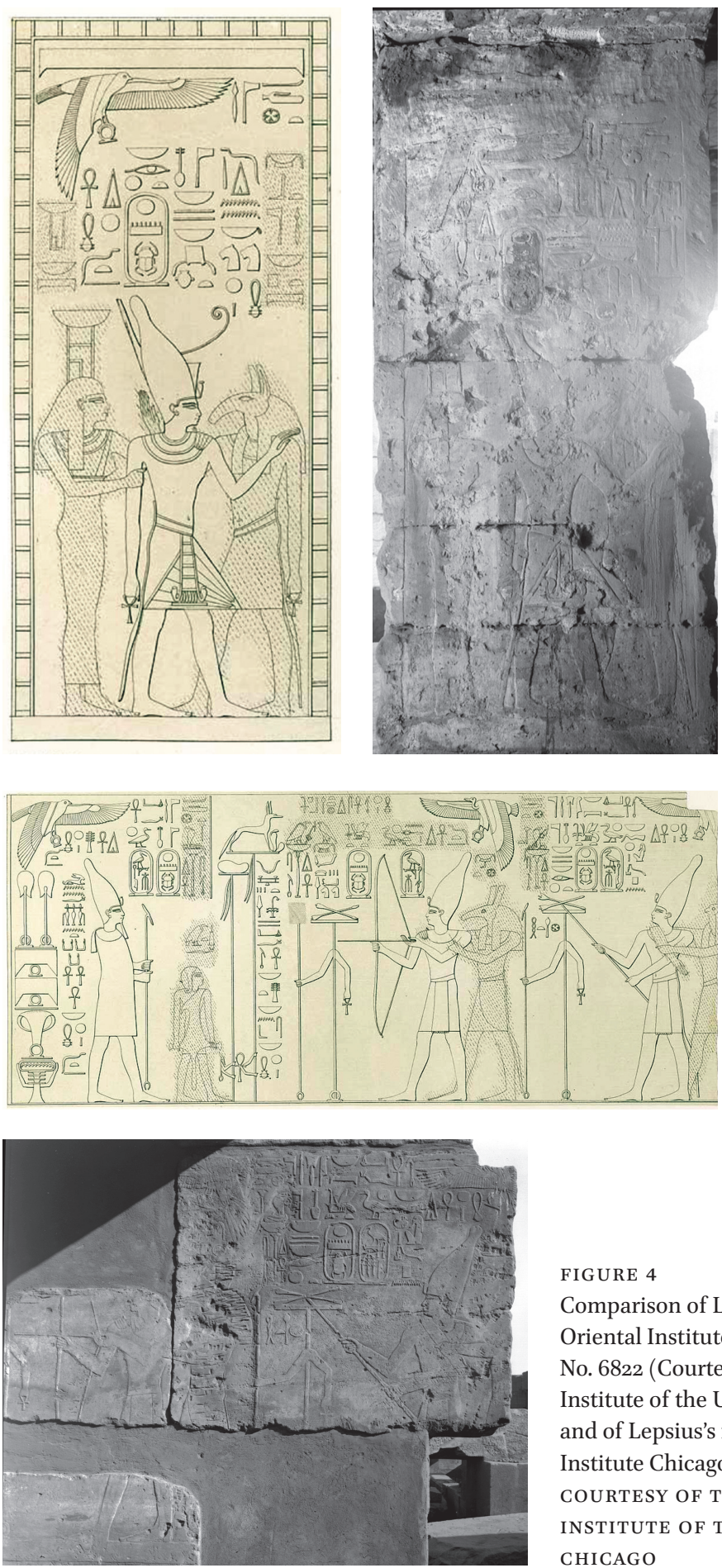

FIGURE 4

Comparison of Lepsius's fig. 35e with Oriental Institute Chicago photo No. 6822 (Courtesy of the Oriental Institute of the University of Chicago) and of Lepsius's fig. $36 \mathrm{~b}$ with Oriental Institute Chicago photo No. 8103 COURTESY OF THE ORIENTAL INSTITUTE OF THE UNIVERSITY OF CHICAGO 


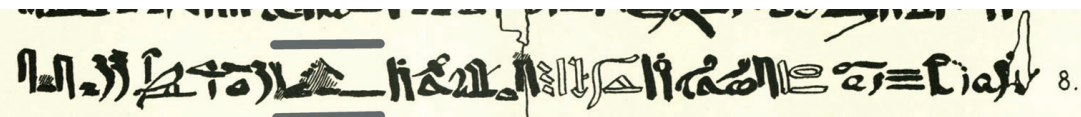

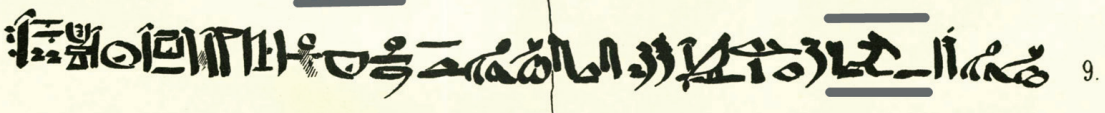

FIGURE 5 Papyrus Berlin No. 3055, col. III, line 8 with a transformed and line 9 with an untransformed Seth animal, both cases highlighted by the present author with two gray lines MÖLLER 1901

interesting and special case in this regard. ${ }^{10}$ The papyrus most probably dates to the 22nd dynasty, and the text is a compilation of 66 spells of the Daily Cult Ritual for Amun in the temple of Karnak (Braun 2013: 76-78; cf. Lorton 1999: 131-145). It employed the sign of the Seth animal to write the god's name ten times altogether, but it has been wiped away six of these ten times. ${ }^{11}$ One of the six wiped signs can be seen in Figure 5 , line 8, and one of the four signs without this treatment in Figure 5, line 9. ${ }^{12}$ The sign is, however, still recognizable even when it was wiped, which is an interesting observation per se. The wiping only affected the central body parts, while the distinctive tail and snout were left unharmed.

Two other papyri belonging to the same lot, Berlin No. 3014 and 3053, also bear Daily Cult Ritual spells written down at the same time, only in this case for the cult of the goddess Mut. In these papyri, all eight Seth animals, which were used to write the god's name, remain untransformed (cf. Möller 19o1).

Scholars used to assume that the wiping of Seth in papyrus Berlin No. 3055 was done by a second hand with malicious intention, during the supposed proscription of Seth (Braun 2013: 77; following Möller 1901: 1). However, one of the problems with Lepsius's interpretation of the reliefs discussed above, applies here as well: the intention to delete the god cannot be confirmed with sources that prove how this was not executed successfully at all. Consequently, alternative explanations need to be considered for the treatment of Seth in the papyri as well, for example that the writer of the papyrus himself wiped the sign immediately after writing it. This assumption is able to explain all the characteristic features of this case: wiping was chosen instead of more successful ways of deleting the sign, for example crossing or scraping; wiping was

10 This papyrus as well presumably played its part in constructing the hypothesis of proscription, since it was purchased by Lepsius in 1845 and brought to Berlin in 1851 (Möller 19o1: 1).

11 Col. I, line 3; col. III, line 8; col. XXIX, line 6; col. XxxI, line 6 (two times); col. XXXII, line 5 .

12 Col. III, line 9; col. XXXII, line 1; col. XXXIV, line 5 and line 8. 
easier as long as the ink was still wet, so that the distinctive elements of the sign were left recognizable; and the writer himself made the choice to wipe or not to wipe during the process of writing, so that not all cases were wiped.

Another practice of transformation of Seth's name in papyri, that was still in use much later, also suggests that Seth was not avoided and not persecuted at a later date. In texts written in the late hieratic script of the beginning of the Ptolemaic period, red ink was often used for writing the names of Seth or Apophis, and sometimes also the words for enemy, evildoer, and the like (Möller 1936:4). But it should also be noted that red always used to be, and still was, the color for highlighting (Backes 2016:15-18), and that in a papyrus called "Papyrus Schmitt" from the Ptolemaic period, for example, one writing of a priestly title is also in red ink (25). Moreover, in his publication of this papyrus (bearing a funerary text with strong links to the Daily Cult Ritual), Burkhard Backes pointed out that only certain writings of Seth were executed in red ink, while others were still written with black ink; and some writings again were written in black, but complemented with the enemy-classifier or drawn with a knife to the head of the Seth animal (17). This treatment most probably had the intention of banishing a potentially dangerous supernatural power in certain contexts, but not of annihilating the god.

In all of these four papyri given as examples, Seth was mentioned in contexts of mythological precedence and his presence in the text was therefore important for the effectiveness of the ritual, ${ }^{13}$ but it was also handled with special care.

The transformations of Seth in relief have hitherto been conceived in Egyptology as a form of negation, but following the contextual evidence presented above, one should start thinking differently. The papyri discussed substantiate the hypothesis that the transformation of Seth was a way of reconstructing the image of this god, of using it, but also of avoiding it, at the same time, in the 22nd dynasty but also still in the Ptolemaic period. The reliefs discussed furthermore prove that those who executed the transformations in later times were not only able to understand the inscriptions and images from earlier times, but also kept using them for their own religious practice. In both media, the images and names were not attacked in wild rage, but with respect to the surroundings and with them still being recognizable afterwards. Consequently, these transformations were affirmative instead of pejorative with regard to Seth, affirming the relevance of his role by transforming his image. They were

13 And notably the name of Seth was still employed in ritual texts in Ptolemaic times. 
malevolent toward the image, but benevolent toward the idea. The intention behind destroying(?) the image of Seth was not deconstructing, deactivating, or deconsecrating it (cf. above), but reconstructing it to affirm its meaning, to banish its power. Following Troels Myrup Kristensen, who analyzed Christian cases of "Breaking the Gods," such a practice of transforming the figures and names of gods in contemporary reliefs can be described as "positively demonstrating the continued vitality of the images as participants in the religious order of the region" (Kristensen 2013: 117).

\section{5}

\section{Conclusion}

A temple ruin gives a dramatic impression to today's observer; a toppled statue or an erased figure of a god from a relief easily let one think of violent attacks on "othered" religions (cf. Kristensen 2013: 107). In the endeavor to study the multiple endings and beginnings of religious transformation, the monuments of distant places and times need to be analyzed more thoroughly. Future work on the transformations of gods in relief and papyri has to consider all levels of context. Seth, for example, is not the only target in reliefs, but was targeted in papyri as well. Finally, not all, but only selected cases of Seth have been transformed.

The case of the transformation of the image and name of Seth used to be understood as a destruction with religious motivation, as an attempt to annihilate this god, to terminate his cult. This was interpreted as an indicator for religious decay, an idea that matched with the general idea of religious decay in Egypt in the first millennium BCE. But the practice of transformation of the image and name of the god Seth is more profitably to be seen within a framework of the continued vitality of Ancient Egyptian religion.

\section{Acknowledgments}

I would like to express my gratitude here to my fellow members of the "Demise of Religions" project at the Centre for Advanced Studies (CAS), Oslo, and to the colleagues of the Norwegian Egyptological society for inspiring discussions of earlier drafts of the paper. And I thank Daniel Neumann, Camilla Di Biase-Dyson, and Heike Behlmer for their corrections as well as Michael Stausberg and Penelope Wilson for their comments on and suggestions for the final draft. 


\section{References}

Allon, Niv. 2007. "Seth is Baal: Evidence from the Egyptian Script." Egypt and the Levant XVII: $15^{-22 .}$

Assmann, Jan. 2006. Ma'at: Gerechtigkeit und Unsterblichkeit im alten Ägypten. 2nd ed. Munich: C. H. Beck.

Backes, Burkhard. 2016. Der "Papyrus Schmitt” (Berlin P. 3057): Ein funeräres Ritualbuch der ägyptischen Spätzeit. Vol. 1. (Ägyptische und orientalische Papyri und Handschriften des Ägyptischen Museums und Papyrussammlung Berlin). Berlin: De Gruyter.

Brand, Peter J. 2010a. "Reuse and Restoration." In Willeke Wendrich (ed.), UCLA Encyclopedia of Egyptology, Los Angeles: University of California. URL: http:// digital2.library.ucla.edu/viewItem.do?ark=21198/zzoo2311q4 (accessed 20 March 2020).

Brand, Peter J. 2010b. “Usurpation of Monuments" In Willeke Wendrich (ed.), UCLA Encyclopedia of Egyptology, Los Angeles: University of California. URL: http://digital2.library.ucla.edu/viewItem.do?ark=21198/zzoo25h6fh (accessed 2O March 2O2O).

Brand, Peter J., Rosa Erika Feleg, and William J. Murnane. 2018. The Great Hypostyle Hall in the Temple of Amun at Karnak. Vol. 1, pt. 3. (Oriental Institute Publications 142). Chicago: Oriental Institute Publications.

Brand, Peter J., Jean Revez, Janusz Karkowski, Emmanuel Laroze, and Cédric Gobeil. 2013. "Karnak Hypostyle Hall Project: Report on the 2011 Field Season for the University of Memphis and the Université du Québec à Montréal." Cahiers de Karnak 14: 193-229.

Braun, Nadja Stefanie. 2013. Pharao und Priester: sakrale Affirmation von Herrschaft durch Kultvollzug. Das Tägliche Kultbildritual im Neuen Reich und der Dritten Zwischenzeit. (Philippika, 23). Wiesbaden: Harrassowitz.

Brunner-Traut, Emma. 2002 [1974]. “Epilogue: Aspective.” In Heinrich Schäfer, Principles of Egyptian Art, Emma Brunner-Traut (ed.), Oxford: Griffith Institute, 421-448.

Bryan, Betsy M. 2012. "Episodes of Iconoclasm in the Egyptian New Kingdom." In Natalie Naomi May (ed.), Iconoclasm and Text Destruction in the Ancient Near East and Beyond, (Oriental Institute Seminars, 8), Chicago: Oriental Institute of the University of Chicago, 363-394.

Connor, Simon. 2018. "Mutiler, tuer, désactiver les images en Égypte pharaonique." Perspective 2. DOI: 10.4000/perspective.11431.

Cruz-Uribe, Eugene. 20og. “Sth ` phty 'Seth, God of Power and Might.” Journal of the American Research Center in Egypt 45: 201-226.

Diamond, Jared. 2005. Collapse: How Societies Choose to Fail or Survive. London: Viking.

Du Quesne, Terence. 1998. "Seth and the Jackals." In Willy Clarisse (ed.), Egyptian Religion: The Last Thousand Years - Studies Dedicated to the Memory of Jan Quaegebeur, (Orientalia Lovaniensia Analecta, 85), Leuven: Peeters, 613-628. 
Eaton, Katherine. 2013. Ancient Egyptian Temple Ritual: Performance, Pattern, and Practice. New York: Routledge.

Fazzini, Richard A. 1988. Egypt: Dynasty XXII-XXV. (Iconography of Religions, Section XVI: Egypt, Fascicle 10). Leiden: Brill.

Gardiner, Alan H. 1931. The Library of A. Chester Beatty: Description of a Hieratic Papyrus with a Mythological Story, Love-songs, and Other Miscellaneous Texts. (The Chester Beatty Papyri I). London: Oxford University Press.

Griffiths, John Gwyn. 1948. “Shelley's ‘Ozymandias’ and Diodorus Siculus.” The Modern Language Review 43(1): 80-84.

Griffiths, John Gwyn. 1970. Plutarch's De Iside et Osiride. Cardiff: University of Wales Press.

Hope, Colin A., and Ashten R. Warfe. 2017. "The Proscription of Seth Revisited." In Camilla Di Biase-Dyson and Leonie Donovan (eds.), The Cultural Manifestations of Religious Experience: Studies in Honour of Boyo G. Ockinga, (Ägypten und Altes Testament, 85), Münster: Ugarit-Verlag, 273-283.

Hornung, Erik. 1996. Conceptions of God in Ancient Egypt: The One and the Many. John Baines (trans.). Ithaca, NY: Cornell University Press.

Hubai, Peter. 2001. "Über die Ursachen des Sieges des Christentums in Ägypten." Numen 48(1): 81-116.

Kahl, Jochem. 2004. "Religiöse Sprachsensibilität in den Pyramidentexten und Sargtexten am Beispiel des Namens des Gottes Seth." In Susanne Bickel and Bernard Mathieu (eds.), D'un monde à l'autre. Textes des Pyramides \& Textes des Sarcophages. Actes de la table ronde internationale "Textes des Pyramides versus Textes des Sarcophages," IFAO, 24-26 septembre 2001, Cairo: Institut Francais d'Archéologie Orientale, 219-246.

Klotz, David. 2013. "A Theban Devotee of Seth from the Late Period: Now Missing exHannover, Museum, August Kestner Inv. S. o366." Studien zur Altägyptischen Kultur 42: 155-180.

Kooyman, Milena. 2017. "Always on the Periphery? Seth and Personal Piety in New Kingdom Egypt." In Camilla Di Biase-Dyson and Leonie Donovan (eds.), The CulturalManifestations of Religious Experience: Studies in Honour of Boyo G. Ockinga, (Ägypten und Altes Testament, 85), Münster: Ugarit-Verlag, 365-376.

Kristensen, Troels Myrup. 2013. Making and Breaking the Gods: Christian Responses to Pagan Sculpture in Late Antiquity. Aarhus: Aarhus University Press.

Kühne-Wespi, Carina, Klaus Oschema, and Joachim Friedrich Quack. 2019. "Zerstörung von Geschriebenem: Für eine Phänomenologie des Beschädigens und Vernichtens.” In Carina Kühne-Wespi, Klaus Peter Oschema, and Joachim Friedrich Quack (eds.), Zerstörung von Geschriebenem: Historische und transkulturelle Perspektiven, (Materiale Textkulturen, 22), Berlin: De Gruyter, 1-40. 
Lepsius, Karl Richard. 1849-1859. Denkmaeler aus Aegypten und Aethiopien. vol. V(III). Berlin: Nicolai. URL: http://edocz.bibliothek.uni-halle.de/lepsius/start .html (accessed 29 November 2020).

Lepsius, Karl Richard. 1851. "Über den ersten ägyptischen Götterkreis und seine geschichtlich-mythologische Entstehung." (Abhandlungen der Berliner Akademie der Wissenschaften, philol.-hist. Klasse) Berlin: Besser.

Lepsius, Karl Richard. 19oo. Denkmaeler aus Aegypten und Aethiopien. Text, Dritter Band: Theben. Berlin: Nicolai. uRL: http://edoc3.bibliothek.uni-halle.de/lepsius/ start.html (accessed 29 November 2020).

Lorton, David. 1999. "The Theology of Cult Statues in Ancient Egypt." In Michael Brennan Dick (ed.), Born in Heaven, Made on Earth: The Making of the Cult Image in the Ancient Near East, Winona Lake, IN: Eisenbrauns, 123-210.

Maggio, Rodolfo. 2017. An Analysis of Jared M. Diamond's “Collapse: How Societies Choose to Fail or Survive." London: Macat.

May, Natalie Naomi. 2012. "Iconoclasm and Text Destruction in the Ancient Near East." In Natalie Naomi May (ed.), Iconoclasm and Text Destruction in the Ancient Near East and Beyond, (Oriental Institute Seminars, 8), Chicago: Oriental Institute of the University of Chicago, 1-32.

McAnany, Patricia A., and Norman Yoffee (eds.). 2010. Questioning Collapse: Human Resilience, Ecological Vulnerability, and the Aftermath of Empire. Cambridge: Cambridge University Press.

Möller, Georg. 1901. Rituale für den Kultus des Amon und für den Kultus der Mut. (Hieratische Papyrus aus den königlichen Museen zu Berlin, I). Leipzig:J. C. Hinrichs. Möller, Georg. 1936. Von der zweiundzwanzigsten Dynastie bis zum dritten Jahrhundert nach Chr. (Hieratische Paläographie. Die Buchschrift in ihrer Entwicklung von der fünften Dynastie bis zur römischen Kaiserzeit, III). Leipzig: Hinrichs.

Nelson, Harold Hayden. 1936. Ramses III's Temple within the Great Inclosure of Amon, Reliefs and Inscriptions at Karnak, vol. 1. (The Epigraphic Survey, Oriental Institute Publications, 25). Chicago: The University of Chicago Press.

Nelson, Harold Hayden and William J. Murnane. 1981. The Wall Reliefs, The Great Hypostyle Hall at Karnak, vol. 1, pt. 1. (Oriental Institute Publications 106). Chicago: The Oriental Institute of the University of Chicago.

Oden, Robert A. 1979. "The Contendings of Horus and Seth' (Chester Beatty Papyrus No. 1): A Structural Interpretation." History of Religions 18(4): 352-369.

Porter, Bertha, and Rosalind L. B. Moss. 1929. Topographical Bibliography of Ancient Egyptian Hieroglyphic Texts, Reliefs, and Paintings, vol. 2: Theban Temples. Oxford: Clarendon Press.

Quack, Joachim Friedrich. 2019. “'Lösche seinen Namen aus!'. Zur Vernichtung von personenreferenzierter Schrift und Bild im Alten Ägypten.” In Carina KühneWespi, Klaus Peter Oschema, and Joachim Friedrich Quack (eds.), Zerstörung von 
Geschriebenem: Historische und transkulturelle Perspektiven, (Materiale Textkulturen, 22), Berlin: De Gruyter, 43-102.

Ritner, Robert K. 2008. The Mechanics of Ancient Egyptian Magical Practice. (Studies in Ancient Oriental Civilization, 54). 4th ed. Chicago: The Oriental Institute of the University of Chicago.

Ritner, Robert K. 2012. "Killing the Image, Killing the Essence: The Destruction of Text and Figures in Ancient Egyptian Thought, Ritual, and 'Ritualized History." In Natalie Naomi May (ed.), Iconoclasm and Text Destruction in the Ancient Near East and Beyond, (Oriental Institute Seminars, 8), Chicago: Oriental Institute of the University of Chicago, 395-405.

Shaw, Ian. 200o. The Oxford History of Ancient Egypt. Oxford: Oxford University Press. Smith, Mark. 2010. "The Reign of Seth: Egyptian Perspectives from the First Millennium BCE." In Ladislav Bareš, Filip Coppens, and Kveta Smoláriková (eds.), Egypt in Transition: Social and Religious Development of Egypt in the First Millennium BCE, Prague: Czech Institute of Egyptology, Faculty of Arts, Charles University, 396-430.

Stapelton, Rachel F., and Antonio Viselli (eds.). 2019. Iconoclasm: The Breaking and Making of Images. London: McGill-Queen's University Press.

Turner, Philip John. 2013. Seth: A Misrepresented God in the Ancient Egyptian Pantheon? (British Archaeological Reports 2473). Oxford: Archaeopress.

te Velde, Herman. 1967. Seth, God of Confusion: A Study of His Role in Egyptian Mythology and Religion, Leiden: Brill.

Vittmann, Günter. 2017. "Grain for Seth and His Divine Companions in Dakhleh (Ostracon Mut 21/4)." In Richard Jasnow and Ghislaine Widmer (eds.), Illuminating Osiris: Egyptological Studies in Honor of Mark Smith, Atlanta: Lockwood Press, 363-374.

Wilson, Penelope. 2005. "Naming Names and Shifting Identities in Ancient Egyptian Iconoclasm." In Anne McClanan and Jeff Johnson (eds.), Negating the Image: Case Studies in Iconoclasm, Aldershot: Ashgate, $113^{-136 .}$

Wong, Jun Yi. 2016. "Raze of Glory: Interpreting Iconoclasm at Edfu and Dendera." Journal of Late Antiquity 9(1), 891-831. 